\title{
When to Act Is to Say: Appointment as Conflictogenic Discourse in the Cameroonian Administration
}

\author{
Celestin Messanga Obama \\ Correspondence: Celestin Messanga Obama, Department of Advertising, Advance School of Mass Communication, \\ University of Yaoundé 2, Cameroon.
}

Received: August 28, 2017

doi:10.11114/smc.v5i2.2693
Accepted: September 25, 2017

Online Published: October 10, 2017

URL: https://doi.org/10.11114/smc.v5i2.2693

\begin{abstract}
Promotion to high office in the Cameroonian administration, appear to be one of the main topic of political communication in Cameroun. The communitarian claims of appointment put both individuals and communities in competitive situations and are often the source of social conflicts. The problem is to understand the focus of political communication on appointment in the Administration in Cameroon and the possible link that it could have with conflictuality in the country. From a theoretical point of view, each act of appointment can be understood as a message from the President of the Republic whose power of appointment is unlimited. The president's acts of appointment; on the one hand; and the demands from communities, on the other, appear to be a kind of communication. Data analysis will be guided by the theory of "the actor and the system". From a methodological point of view, we used documentary observation in the national and international press. We also had an in-depth interview with a former minister who, however, requested anonymity. Finally, our 26-year service as an employee gives us the advantage of experience gained through participatory observation. It appeared that appointment, through the numerous and consistent advantages that it confers on the promoted, thus appears to the citizens, as the main means of access to the fortune from which the covetousness of both the individuals and their communities of origin arises. Unfortunately, the state is unable to meet all expectations. However, individual, as well as community, strategies of access to appointments expose the nation to more division than cohesion.
\end{abstract}

Keywords: appointment, elite, conflicting stakes

\section{Introduction}

The appointment, that is, the promotion of an individual to high office, in the Administration is generally perceived as an act of recognition of the competence and dedication of the promoted person. In the communication perspective, this act can be perceived as a message sent to both the promoted person and the public at large. In this perspective, we will analyse the appointment, not in the administrative aspect, but in its communicability. Generally speaking, appointments are based on two systems: the spoil system, which is based on the management of political equilibrium and the merit system, which is based on objective criteria for access to appointment. The aim (message) in both systems is the efficiency of work. Each of these administrative systems can be considered as a sort of discourse in the political field. In this logic, appointments, in either case, is a challenge that should inspire more commitment and even some concern in the appointed person. As part of the fight against corruption and embezzlement of public funds in Cameroon, known as "Operation Sparrow-Hawk", many senior officials of the Administration are found in prison. The discourse delivered through this action is that, appointment is not a gift for the enrichment of the promoted person but a commission to high duties. However, despite the weight of responsibilities and the risks associated with it, the promotion of an individual to senior positions in the Cameroonian Administration gives rise to great celebration. Such celebrations suggest that audiences (individuals and communities) perceive a completely different discourse upon an appointment. Understanding the focus of both individuals and communities on access to appointment, despite the burden of responsibility and the associated risks, is our main concern in this paper. The focus on access to appointment appears as a feedback discourse from the citizen.

In Cameroon, and as a matter of principle, equal opportunities for access to the civil service are asserted by the public discourse but the practice of regional balance and favouritism which have been upheld as principles, make the modalities biased. In this context, each act of appointment is interpreted as a message of the President of the Republic. Understanding the focus of political communication on appointment in the Administration in Cameroon and the 
possible link that it could have with conflictuality in the country is the main problem this article proposes to solve. What speech do the celebrations of the appointment of a citizen convey in Cameroon? This is the main question that will guide our analysis. We will assume that appointment in Cameroon foster the emergence of a system of gratification.

On the methodological level, we intend, in an anthropological approach, to limit our observation to ministerial functions, general managers in parastatals and equivalent posts, since the chain of appointments is long. This approach leads us towards a qualitative approach to data collection. This will consist of a documentary observation focusing on the national and international press. We will look for stories about acts of appointment and all texts dealing with this theme. Only articles dealing with the topic will be selected. The selection of reference documents in this context will be based on additional information and not on a systematic basis. Our 26-year service as an employee gives us the advantage of experience gained through participatory observation. An interview with a former minister who requested anonymity completes these tools. The objective in this process is to identify the representations that social actors make of appointments and the issues that arise from it. We will hear from social actors like Alfred Schütz (Corcuff, 1995), the people who act knowing what they are doing as they do.

From the theoretical point of view, we will remain in the general inkling of constructivism. This general framework will enable us to observe how, through what is said on appointment in the Cameroonian administration, the imaginary and the stakes that regulate the socio-political life are constructed in Cameroon. Within this framework, we borrow from sociologist Michel Crozier's theory of "the actor and the system" (Crozier and Erhard, 1992)

\section{Functional Necessity of the Post of Liability}

Cameroon, according to UNDP (UNDP, 2016), is classified as a low-human development country. Its economy is backed by the informal sector which occupies $90 \%$ of the working population and provides $30 \%$ of the GDP. With an unemployment rate of $30 \%$ and the precariousness of the informal sector, only the public sector guarantees access to a regular and consistent income. The State is the main employer, but the public sector wage level does not guarantee the material comfort of civil servants and other contractual workers. However, it is the appointment, due to the multiple and consistent advantages it brings to the promoted, which gives access to the best and, as a result, all employees in the public sector scramble for appointments.

The legal approach places work within an organization, in the normative field. The social actors are subject to instructions and rules of the organization, which constitute constraints or "the bureaucratic system" to use Michel Crozier's expression (Op. cit.). To the sociologist Max Weber (Mulder, 2017), modern administration appears as a hierarchical organization in which there is a clear separation of tasks and division of labour. Effectiveness in this perspective depends on compliance with instructions. Instructions often flow in a vertical order from top to bottom (top / bottom model). In this perspective, positions of responsibility which are characteristic of the hierarchical level concerned are clearly a functional necessity in any organization.

According to Michel Crozier (Op. cit.), things do not always happen in a harmonious way. Many dysfunctions occur, the rule of law being often insufficient to ensure social equilibrium. Indeed, power relations are deployed in a much more practical way, requiring empirical observation on the ground. While the French sociologist is more interested in the emergence of peripheral centres of power, observation of the Cameroonian terrain reveals two types of dysfunctions linked to the mobilization of human resources in the administration. One is linked to the hierarchy's source of power; the other refers to individual dynamics. These dysfunctions make the appointment system in the Cameroonian administration a particular type, distinct from both the spoil system and the merit system.

It is important to note that in relation to the source of power, different levels of responsibility in the Administration in Cameroon come from the same source, sometimes relativizing the principle of the hierarchical devolution of authority. According to Christian De Visscher and Gauthier Le Bussy, the spoil system rests, among other things, on the argument that

"...administration is a competitor power to political power; the latter must therefore protect itself by appointing the faithful "and that" politicization enables optimum cooperation between administrative and political personnel. It makes it possible to "oil the wheels" between the government function and the administrative function" (Le Bussy, 2001).

This assumption is based on the principle of political alternation, whereby one political team gives way to another, often through elections, thus leaving the government with an administration that does not share its values. In this case, the administration appears to be a competitor to the new political power.

\section{Functional Contradictions of Appointments in Cameroon}

In Cameroon there is neither political alternation nor genuine competition between politics and administration, at least in the medium term. The longevity of the regimes is such that the border between the government which is a political 
institution and the Administration is blurred, with government officials and members being predominantly militants of the political party in power.

The merit system, as asserted by the two previous authors, is based on the idea that "politicization escapes [...] any control. It encourages "catching up", ends up spreading to all levels of the administration. A vicious circle appears: mistrust of the policy, demobilization of the officials in office, reinforcement of the cabinets and new political appointments ". The message that emerges from such a system is that of the offer of "a neutral administration, necessary to ensure the continuity of the public service in the event of political alternation". In Cameroon, and as a matter of principle, equal opportunities for access to the civil service are asserted and guaranteed by entrance examinations into different schools, giving rise to integration into the various bodies of civil servants, but the practice of regional balance and favouritism which have been upheld as principles, make the modalities biased. This principle of regional equilibrium also intervenes in appointments where it falls within the "discretion" of top management. The result is a discursive display of objectivity contradicted by an increasingly sophisticated discriminatory practice. The phenomenon is such that mobilization through social networks to denounce the failure to respect this regional balance in admissions at competitive entrance examinations or in certain appointments is increasingly strong.

The power of appointment in the Cameroonian Administration is devolved to the executive and is exercised by the President of the Republic on the one hand, and the Government on the other, in accordance with Law No. 96-06 of 18 January 1996 Revising the Constitution of 2 June 1972. Article 8, paragraph 10, says: "He shall appoint to civilian and military posts of the State". It appears here that the power of appointment of the President of the Republic is unlimited. As head of the executive, the president is the cornerstone of the system and, as such, has a pre-eminence over the Army, the Police, the legislative, judicial and even the ruling party of which he is also the chairman. Such a central position makes the president the major actor in the devolution of the power of appointment in all sectors of public life in Cameroon. Jean-François Bayart shows the pre-eminence of President Ahmadou Ahidjo in the appointment of officials in the Cameroonian Administration (Bayart, 1979). His directives as leader of the ruling party, determine promotion to functions that are deemed elective. In fact nothing seems to have fundamentally changed. In this respect, Fanny Pigeaud declared:

"... he has not loosened his grip on the administrative apparatus: as in the period of the one party state, Biya maintains full control, thanks to the power of appointment. The president continues to make and unmake the careers of senior civil servants, without being accountable to anyone" (Pigeaud, 2011).

Speaking of the election of the President of the National Assembly in 2007, N. Siki, Parfait (2007), addressed the action of President Paul Biya against Adama Modi, Member of Parliament for the Mayo Kani constituency, on the list of the Cameroon People's Democratic Movement (CPDM), the ruling party. It is written:

"... the National President of the CPDM, Mr Paul Biya, set up an ad hoc Disciplinary Committee on 7 September in the wake of the reorganization of government. This Peer Review Tribunal [...] is responsible for reviewing the disciplinary file of Mr Adama Modi".

The motive of the indictment of this Member of Parliament was revealed later, when the article stated: "The deputy of Mayo Kani opposed the candidature of Mr. Cavayé Yeguié Djibril to the post of speaker of the National Assembly, a candidate nominated by the Head of State himself". It is revealed here that opposition to a candidature approved by "the hierarchy" (National Party President) is perceived and treated as an offense. This problem takes on a particular dimension because the President of the Party is also President of the Republic.

The central position of the President of the Republic in relation to all the authorities of power makes it the focus of the solicitations of all the social components. Each of its acts, in this case, is analyzed as a discourse and any form of reaction is also perceived as a discourse. A sort of communication between the President of the Republic and the rest of the social actors is thus established through the acts of appointment, all the more because direct contact does not exist at all. In accordance with Michel Crozier's above mentioned theory of the actor and the system, several strategies for social positioning through the appointment in the Administration are developed around the President of the Republic. Top military and civilian officials perceive the President's endorsement as a launching pad that enables access to a position of responsibility in the senior administration. Unfortunately, the president can only know his compatriots through his intelligence networks. The actors of this network, conscious of their importance, work to constitute political clienteles based on the fact that they propose appointments to the President. They thus become sub-powers not only in the eyes of those who have benefited from their services, but also to those in search of promotion. According to this logic, any person likely to have any closeness with the President of the Republic falls into this category. With the principle of subordinates' proposal to appointment by the hierarchical leader, the devolution of power of appointment to the lower stages of the administrative hierarchy follows the same logic to the lowest stage. The result is a sacralisation of the personality of the leader, whatever the level. 
- Individual promotional dynamics, on the other hand, affect the various strategies developed by public officials, regardless of rank or position, to gain access to appointment. In Cameroon, individual dynamics make use of the numerous networks of powers, internal or external to the Administration. With the high school attendance of young people and the low employment prospects in the private sector, the number of competent agents, committed and zealous activists, has exceeded the possibility of appointment in the Administration. As a result, more and more applicants undertake to make use of some sort of sponsor or godfather, understood here as persons who have good relations with those who have either the direct power of appointment or those who know those who have this power. Popular thinking in Cameroon expresses this process as follows: "one becomes someone behind someone who knows someone". The reference to popular thought here reveals the popular inking of social representations on this subject. The different positioning manoeuvres are the basis of a certain form of clientelist policy that tends to ramify itself over time. This popular discourse is regularly relayed by the local press, which consecrates this phenomenon.

A talented journalist from the Public Broadcasting Authority (CRTV) who had reached the age limit for retirement had arranged to cover the national day parade on 20 May 2013. In his report he had publicly said "Au revoir" to the nation, certainly in the hope of being listened to by the President of the Republic himself. Sometime later, he was granted an extension of activity, followed by appointment as Director General of this Institution. He later expressed his gratitude as follows:

"This man, this president, has not only, as I have heard and read here and there, he has not only saved me from retirement, a retreat presented rightly or wrongly as a condemnation and which would have become unavoidable for me in exactly two months to the day. He, more fundamentally and literally, saved my life" (Ndongo, 2017)

This quote expresses not only the satisfaction with the confidence received in this appointment, but also the gratitude of "a known person" facing the misery of retirement. This type of discourse maintains the idea of gratification now attached to appointments in Cameroon.

The Administration appears to be the sector most sought after by jobseekers in Cameroon and those who manage to gain integration into it greatly desire appointments, both at top and low level. According to the National Institute of Statistics (INS, 2010), "the majority of unemployed citizens, prefer jobs in the public sector or in the formal private sector, because of the job security these bodies offer. By specifying "for reasons of security in employment", the report of the NIS shows a motivation oriented towards retribution. Indeed, the pleasure or the desire to carry out a task is of ever diminishing concern for public officials as well as for the young people in search of employment. The criteria of attendance and punctuality at work are good indicators of motivation at work in the Cameroonian Administration. The abundant dissemination of radio announcements calling for the return of certain agents, who have been absent from their workplace sometimes for months, can be seen as an indicator of the low motivation for the work of such agents. One explanation for the delay and absenteeism of public officials is the low level of wages in relation to the cost of living. In an article published in the online newspaper l'Actu (2013), we read:

"Moreover, many civil servants without real positions of responsibility complain that senior officials take all the advantages". Even for small missions and other on-the-ground checks, they go themselves so as to receive all the benefits. With that, how do you want us not to look elsewhere? ", a construction engineer asks."

By emphasizing "high-level officials get all the benefits", the above quote reveals the fundamental reason for interest in appointments. This observation enables us to posit that, only an appointment offers a fulfilment to the worker in the administration in Cameroon.

Faced with the rising cost of living caused by the economic crisis itself, aggravated by both the devaluation of the CFA franc and the drastic cuts in salaries carried out by government between 1992 and 1993, interest in appointment in Cameroon is perceptible in the media. It is observed that the formation of government is a permanent concern. Indeed, even in the aftermath of a cabinet reshuffle, some newspapers do not fail to announce "a large-scale overhaul" in the more or less near future. Only one year after the ministerial reshuffle of October 29, 2012, the newspaper L'Epervier, in its December 25, 2013 issue, says:

"Paul Biya demonstrates day after day that he is the master of Cameroon; that his time is not that of his people, much less, that of his ministers. As soon as the page of the legislative and municipal council elections was turned, the whole Republic waited for the traditional government reshuffle the following week. Two months later we are still waiting!"

This article betrays a sort of impatience in the national opinion. The reading of appointment in Cameroon has ended up being a source of inspiration for some artists. Donny Elwood, a Cameroonian musician, titles one of his tracks "my brother is up there". In this song, the author evokes the positive revolution that the appointment of "his brother" will 
bring to his life. For the ordinary Cameroonian, "to be up there", means to be wealthy, to have prestige. An empirical observation shows that the appointment of a public official coincides with an increase in the standard of living of the public official and that the loss of a responsibility is accompanied by the opposite effect.

The mere appointment to government entitles officials to a fixed annual allowance of not less than fifty million CFA francs (about $€ 76,000$ ) in terms of: equipment costs, vehicle credit, and others. Moreover, according to the interview with our former minister, the appointee receives a quarterly grant of 900,000 CFA francs for fuel, a semi-annual housing allowance of 1,100,000 CFA francs and so-called sovereignty valued at 15,000,000 CFA francs per quarter. According to the same source, all these premiums are crowned by a monthly salary. According to an article on www.237online.com, titled "Cameroon - Government-Expenditure: Survey of Ministers' Salaries and Benefits - What our Ministers Cost the State", citing Decree No. 2000/285 of 12 October 2000 fixing the rates of daily allowance and the conditions of travel on mission for members of government and equivalent positions, a Minister of State earns 794,651 FCFA. A minister, on his part, ends up with 679,297 FCFA comprised as follows: 253,876 FCFA as basic salary; 171,975 FCFA for hardship allowance and 253,446 FCFA for special charges. A summary calculation gives us an average monthly income of between 6 and 10 million CFA francs (between 12,000 and 15,000€) depending on whether it is a Secretary of State, a Minister or a Minister of State. This range represents the monthly income of nearly 30 Executives who have reached the highest level of the salary grid of the Public Service. According to the salary scale for civil servants starting July 07 , 2014, the highest basic salary (Category A2, Exceptional class, index 1140) is 353,526 F (approximately $€ 539$ ). The salaries of Directors-General of parastatal corporations vary between 6 and 12 million CFA francs $(€ 7,600$ and $€$ $18,000)$. It should be noted here that these are only fixed statutory income.

There are many other benefits such as: mission and medical care allowances. In an environment dominated by corruption, it is not superfluous to identify various services received from employees as well as from other social actors (economic operators, politicians, peasant communities). It is common, for example, for a businessman to supply construction equipment (sand, cement, concrete irons, sheet metal, etc.) or other types of goods without a direct counterpart to the home or the building site of an official, to inform the interested party only afterwards. By publishing these data, the media contribute to the consolidation of the idea of gratification of the appointment that has already been conveyed by the standing of the promoted person.

The media certainly add, either by exaggerating the facts in some governance cases or by inventing others. Among the cases in the Cameroon Chronicle from the late 1990s to the early 2000s was a Minister of Finance who was accused by the press of misappropriating more than one billion CFA francs $(1.5$ million $€)$ of VAT into his private account. This minister has been sentenced by the courts, however, for amounts that were huge but lower than what was announced in the media. In the same vein, the Cameroon press has echoed what has been called the telephone tapping case. Excerpts published in the national press show that two of the recorded members of government were concerned, among other things, about the fortunes of their "colleagues-adversaries" (Le Messager No. 650 of 11 August 1997, Expression No. 160 of 18 August 1997, Le Jour of 08 March 2012). In the latter case, no amount is advanced but it is learned that the fortune in question could sustain an armed rebellion for several years. Such a representation speaks volumes about the size of the said fortune. The position of responsibility, in this case becomes speaking and the speech that it delivers is that of the enrichment and prestige of the holder contradicting the description as "priesthood" made by President Paul Biya in one of his speech to the nation.

\section{Appointment in Ruling Party Support and Maintenance of the Electoral "Village"}

In a context marked by three decades of economic crisis in Cameroon, the inadequacy between supply and demand is a political boon. The rulers, on the one hand, and the ethnic communities on the other, see this as an object of political bargaining. Each of these components makes an instrumental reading of appointments. While, at the level of individual actors, appointment is perceived as the main means of access to wealth and prestige, it is perceived, at the level of top management, as a political lever that allows both the maintenance of "social balance and the preservation of power". The demands by ethnic communities for the appointment of their elite do not seem to displease the rulers. On the contrary, politics has made it a strategy for the preservation of power.

In relation to social equilibrium, the State in Cameroon, under the effects of the economic crisis, has been unable to ensure that the population meets their individual and community needs. In a cultural context where solidarity and belonging to the group are strong, appointment plays a decisive symbolic role. Thus, the promotion of an individual is perceived as a kind of patronage paid to a whole community for its loyalty to the President of the Republic. It therefore creates satisfaction and recognition in the group. An article in the evening newspaper "How Biya names his Ministers," published in the website AfricaPress.com (2013) says:

"Everything has been politicized to excess, so tribalized, to respect "social justice" in sharing the "national cake"; an ultra-tribalization which ensures that in Cameroon, whenever an individual is appointed, the citizens 
from his place of origin do not hesitate to bow in official thanks to the President of the Republic. We finally understand that it is the tribe that is appointed".

It follows from this quote that the state is perceived by different social actors as a "cake" for consumption by the community. The elite are perceived as the proxy that emanates from each group, to take part in the sharing, on behalf of the group. The reading in this context of the appointment is such that, through the promotion of a single individual, the Head of State succeeds in winning the sympathy of a community better than he could have done through social investments (roads, water supply, electricity, schools, dispensaries, etc.).

Because the communities can thus identify with their administrative elite, the product of the appointment, the state can easily play on the socio-political equilibrium, the appointed person becoming, at the same time, a kind of fuse that is shut-off in case of dissatisfaction of the base. The principle is so entrenched in the political mores that Cameroon can today boast of having invented a bi-parliamentary system without government. Indeed, because the ministers are appointed (tacitly, no text clearly stipulating it) to represent their communities of origin, the members of the government will behave like sorts of parliamentarians. The position of responsibility becomes a kind of bonus that rewards good communities. Louis-Marie Kakdeu declares:

"The lack of accountability and the rise of the public administration wasteful spending in Africa are contrary to the principles of public management applicable in a democracy. Appointments, assignments, public procurement, recruitment, are rather tools of payment for "electoral soldiers". This logic of electoral rent that blocks social channels of progress is opposed to the logic of value creation that leads to development» (Kakdeu, 2014).

In such a context, the appointed personalities will work more to ensure their leadership than to achieve any objective. These are ministers as well as other senior officials such as the Directors-General.

With the adoption of pluralistic democracy in Cameroon in 1990, an appointment is seen implicitly as a request for support for the former single party that has now entered into competition with other newly created political parties. Those promoted are implicitly obliged to use everything that comes under their control with the promotion (company vehicles, fuel, etc.) for the victory of their "mentor" during the political contests. The community of origin constitutes what Professor Roger-Gabriel Nlep (Mandjack, 2007) called "the electoral village". Following the appointment of a state clerk to high offices, the community of origin of the promoted individual organizes a meeting of thanks to the President of the Republic. It is during this ceremony that the community, as a sign of gratitude to the president, engages with a motion of support and deference, to express all their gratitude to the benefactor president and renew "their unwavering support". At the symbolic level, the meeting of thanksgiving aims to show the President of the Republic that the community approves his choice of the promoted person who thus becomes the conveyor belt between them and the supreme power. In the course of the 2011 presidential campaign, we heard a militant addressing an elite (Director-General of a parastatal company) appointed as the chairman of the Communal Campaign Committee of the ruling party:

"Son, you come to ask us to vote for Paul Biya but Paul Biya never came here. We're going to do what you're asking us to do but tell Paul Biya that we're not voting for him but for you. Therefore, it is to you that we address our grievances ..."

For this speaker, the "son" he has in front, is a kind of dismemberment of the personality of the president-candidate. Not being able to see the President face to face to speak to him, he does it through the "son" that he has before him.

The practice of thanksgiving meetings is so entrenched in the political habits that some analysts consider it as a grid of reading. After the government reorganization of December 9, 2011, Le Messager, a daily based in Douala, expressedly noted a political problem in the Mfoundi Division, in which Yaoundé, the national capital, is located. This, despite the promotion of four of its "sons", to the post of minister. The report, which is based on the failure of this area to organise a meeting of thanks to the president, suggests that these demonstrations constitute a discourse that reveals the perception of the actions of the head of state by the community of the promoted person.

\section{The Insufficient Offer of Appointment and the Emergence of Conflict-Bearing Speeches}

The exponential increase in the number of national executives in all sectors of public administration, including in parastatals, began to raise the problem of promotion during the 1980s. With the structural adjustment and disengagement of the State from economic activities in the 1990s, appointment opportunities have been reduced as a result of the closure of a number of parastatal enterprises such as CELLUCAM (pulp production), SOCAME (Fertilizer production), CAMSUCO (Cane sugar production), (ONCPB) etc. Similarly, some others have been transferred to private operators (CDC, SOCAPALM, HEVECAM, etc.). The social consequence is the aggravation of unemployment with, on the one hand, the reduction of the field of appointment of public authorities. The regional equilibrium policy, 
which favoured a balanced representation of the different regions of the country in the appointments, and which sometimes tended to put at the same level, officials of disparate intellectual levels, was also beginning to provoke conflicts. Indeed, while the beneficiaries brandished the under-educated regions clause to justify these inequalities, others raised the question of merit to demand equal treatment of all in appointments. It is in the same vein that the English-speaking question, to which we shall return, is situated.

The corporatist and ethicist reading of appointments, suggests the idea of appropriation of the post of responsibility by a fraction of the population to the detriment of the others. This creates confusion between the institution and the person appointed to run it. The public action expected of the citizens of the post then becomes a source of conflicts. Ethnicity, initiatory orders, sociolinguistic groups are the three main axes that focus attention in this reading in Cameroon. Moreover, the fortune and prestige conferred by the position of responsibility gives the idea of "a part of the national cake" granted to an individual and his group of belonging. Such a perception is in itself a political discourse, according to which positions of responsibility should be "distributed" equitably among different components of the nation. This perception is due to the fact that the state is incapable of providing the population with the expected development opportunities. Indeed, entangled in the economic crisis and under the constraint of structural adjustments, the State of Cameroon has proven to be incapable of solving all the development problems of its people.

At the social level, urban unemployment has placed the majority of the working population a precarious situation. In rural areas, the abandonment of support for peasant activities by the public authorities, the isolation and falling prices of agricultural products have weakened the peasant world. The appointment, thenceforth, has a political dimension because the hopes of the peasant communities are now turning to the civil servant relatives. The strategies around the appointment to a position of responsibility thus pass from the stakes of individual survival to those of collective survival. The civil service, the army and the elective posts in politics, become the main means of access to fortune and prestige. In the absence of professional arguments, since the number of executives has increased beyond the possibilities of offering appointments, some individuals develop positioning strategies. There is, on the one hand, the esoteric channel and, on the other hand, the mobilization of community demands.

\section{- The Initiatory Circles}

In Cameroon, esoteric ascent into social advancement has taken on a particular scale, to the point of overcoming the criteria of competence. The initiatory circles (Freemasonry and Rosicrucian) appear as the most influential cadres in the promotion of the elite. Much ink has flowed on the subject both in the national and international press. These initiatory orders are accused of promoting only their followers. The difficulty of verification lies in the fact that these are organizations governed by secrecy or "omerta". However, the coverage of these organizations by the national and international media gives some visibility. La Tribune de l'Est, in its edition of January 27, 2017 titles: "Cameroon under the threat of sects and homosexuals", underlining the strong hold of initiatory orders (sects) in the promotion of the elite. Indeed, the body of the article reads:

"...Cameroon is a secular and independent state ". Now, in the reign of the New Deal government, sects openly make the law. To succeed in a competitive entrance examination to top government posts, you must belong to a group. To get a good appointment, you have to show "white paw' (that is prove your allegiance to the sect)".

This is the translation of an unverified general opinion. Beyond national borders, the problem is not without attention. An article in the French daily Le Figaro, titled "Biya's Cameroon, which is hidden by secret societies" says:

"Everywhere in Africa, occult forces participate in power but nowhere else, as much as in Cameroon." In the administration, the senior civil service, politics and the University, 95\% of the appointments are made in the light of membership in a sect," according to a Professor of Political Science, Magellan Omballa. He himself was offered entry into an order by a minister whose adviser he was. "He said to me, 'You are not one of us, we must join'. I refused. The minister then made it clear to me that my promotion would be blocked", the professor says".

Two principles emerge here: on the one hand, the strategic organization of mystical orders to promote access to appointment to their members and, on the other hand, the disqualification of non-members in access to appointments. In an interview with Jeune Afrique magazine, Hervé-Emmanuel Nkom, presented by the newspaper as "a high-ranking Cameroonian officer of the Grand Orient", says:

"After their university training, Africans also find in Freemasonry the means to" Permeate a secular way of life. This allows them to open up to equality, parity, democracy or social justice. Others consider that masonry can help to get a promotion or to accelerate a career, but it is a deviance" (Nkom, 2012)

It appears in the second part of this paper that many of those who adhere to esoteric circles are motivated by the hope of social advancement through appointment. According to the same newspaper, the hope of promotion aroused both by 
Freemasonry, the Rosicrucian Sect and others, is explained by the affiliation of African leaders to these mystical orders. In the same vein, the newspaper declares:

"For more than twenty years, the French National Grand Lodge (GLNF) has carried out a broad offensive in order to establish itself in the circles of African power where ministers and heads of state have already been initiated".

This assertion reinforces general opinion that appointment to high administrative functions is conditioned by adherence to initiatory orders.

The multiplicity of initiatory orders itself gives rise to a rivalry between them. The article in Le Figaro (Op. cit.) says:

"The highest authorities of the Cameroonian State are supposed to have belonged to or still be members of it: ministers, generals, directors of parastatals ..." The Rose-Cross has been very powerful in Cameroon, explains Magellan Omballa. It then experienced an eclipse in favour of Freemasonry, but recently it seems to be coming back in force."

The Cameroonian press regularly addresses this issue, accusing the rivalries between initiatory orders of being the cause of social rivalries in the country". The secret functioning of these circles urges them to veil their fundamental interests and motives and to present artificial motives in the public space. In this case, the appointment appears as a discourse that presents the initiatory orders as the exclusive way for access to prestige and fortune. The solidarity assigned by opinion to the fraters tends to assimilate the lodges to real ethnic groups, because of the micro-cultures they generate. On the other hand, they tend to be closed to others and thus develop sectarian attitudes. The sectarian tendency of these circles of influence is stronger than that of the real tribal belonging which is much more decried in public discourse. In spite of the negative perception of these orders by public opinion, the suspicion of belonging to senior officials of the Administration (Ministers, General Managers, etc.) constitutes a kind of publicity which presents them as the only means of access to fortune and prestige. The mobilization of initiatory orders by the elite for the purpose of social positioning appears ultimately as the greatest conflictogenic action, insofar as each of these circles tends to exclude not only the uninitiated but also the initiates of the competing orders.

\section{- Community Claims}

Because communities are often summoned for the appointment of the elite, each high official is under strong pressure from both his social group, his friends and his religious brotherhood. Those who resist such solicitations are fiercely opposed by those who find it unfit to protect the group or to "share with their own". Ethnic reading of the distribution of new cadres has allowed certain groups to be placed in a position of favour over others. The Dutch anthropologist Peter Geschiere shows how the school and, consequently, the positions of responsibility in the administration succeeded in placing the Maka, an ethnic group in the Eastern Region, in a position of ascendancy against the Yebekolo of the Central Region, their former masters of the pre-colonial period (Geschiere, 1995). Such a reading of the position of responsibility evacuates the preoccupations of performance both in the source of the appointment which in this case is the supreme authority, and in those receiving the promotion.

The position of responsibility, which is the object of covetousness on the part of all agents, at different levels, will create a perfidious competition for the appointment. Since the availability of positions is not usually the subject of a call for candidacy, networks of relations are being formed in order to control the availability of the posts. Those managers who do not feel reassured deploy their ingenuity to torpedo the job, in order to bring down the incumbent. The manoeuvres used for this purpose are numerous. They range from anonymous letters of denunciation, through the secret removal and dissimulation of official documents, to the release of "scandalous" information on the management of the incumbent to the media. In 1998 a Postmaster General, who had suspended all his major collaborators from signing off, found himself in difficulty in the National Assembly during the defence of his budget because the files had been deliberately misrepresented by his discontented collaborators. In this logic, the middle managers placed under the authority of the senior official serve as a relay to these rivalries.

The main stake of all these jousts is fortune, the State through its redistributing function, appears like a cash cow that everyone seeks to milk without worrying about the health of the beast. However, in the face of the vacuum created by the withdrawal of the state from peasant activities, hopes turned to the local elite. The senior administrative official is tacitly confronted with a double responsibility: he is accountable to the administration and to the local population. The elite are thus responsible for the creation and maintenance of roads, schools, health centres and many other social infrastructures. To these actions must be added the various forms and instances of personal assistance given to these relatives whose impoverishment is ever increasing given the hard times. It is therefore with good reason that the community feasts at each appointment of one of its members. There is thus a de facto ethnization of appointments in Cameroon. The phenomenon is so common that when there is an appointment to some high function, the concern of 
opinion is not on the competences of the promoted but on his ethnic origin.

Conversely, disavowal of responsibility often provokes negative reactions from the fallen community. Following the arrest of a former Minister of Territorial Administration and Decentralization, Le Messager, in its edition of 18 April 2012, published the interview of a certain Mocktar Oumarou who it describes as an "Opinion leader" under the title: "Biya strikes the northerners, the fight begins". Through this title, this newspaper assimilates the arrest of an individual to animosity against a whole community. The community reading of appointments increasingly places ethnic communities under manipulation of the elite who use it to claim positions in the senior administration. In the popular imagination, the action of the state tends to dissolve in the individual action of the elite. A road, a water point, a school, built in a locality will be perceived more as resulting from the work of the elite than as the institutional action of the State. In this logic, each ethnic group (the Bamiléké, the Bamoun, the Beti, the Sawa, the Moundang, the Bayangi, the Banso, etc.) or community sharing a certain identity (Anglophones, Francophones) will "fight" to claim either the appointment of their elite or the access of their members to the public service since this is the framework through which the appointment becomes accessible.

At the creation of the Ecole Normale Superieure de Maroua in the Far North, the elite of the three administrative divisions of this region mobilized to demand the priority recruitment of students from this socio-cultural space. The same is true of what constitutes the "Anglophone problem" in Cameroon. Dieudonné Essomba, in an article entitled "The Anglophone Problem: What the government refuses to accept" says:

"By becoming a sort of deity, it (the State) has claimed to provide to all, schools, public latrines, roads, dams, health centres, water points, ensuring security, peace, social security, in short, everything that is imaginable. The consequence is that it has paralyzed all the indigenous possibilities of organization and community pooling of efforts, thus becoming the exclusive centre of myriad claims and claims to which it is totally incapable of answering" (Essomba, 2016).

In the light of the preceding analysis, the English-speaking problem appears as the expression of a ras-le-bol of a marginalized fringe of the region administered by the British during the colonial period. It is in fact a national problem, which emerges in this part of the country thanks to the free expression inherited from the indirect rule applied by the British administration and which differentiates it from the more submissive and "muter" francophone part. One of the consequences of such a dysfunction is the construction of inefficient but politically significant infrastructures. Such strategies oblige the State to shift its development objectives towards more political, peace and security-oriented ones, thus undermining any possibility of development.

\section{Conclusion}

Understanding the focus of attention on appointments in Cameroon despite the burdens and risks associated with it has been the main obscure point to elucidate in this article. We hypothesized that appointment to high administrative functions in Cameroon is part of a principle of gratification and not of commissioning to accomplish tasks. Following the discourse of certain public actors in the national and international press, we found that, in the context of general poverty in Cameroon, the high remuneration on the one hand and the numerous benefits linked to appointment have the effect of considerably increasing the fortune and the prestige of the promoted. These advantages make the appointment to be perceived as a modality of redistribution of the national patrimony. The opacity of nomination criteria is also a discourse that suggests, in the popular imagination, that the appointment is not necessarily linked to competence but to a network of relationships. Work in such a context loses its value, as unnamed executives essentially deploy their ingenuity only to gain access to an appointment or to draw benefits that, work, in itself, cannot offer them from the administration. Such a reading makes appointment in the administration not a professional motivation, but a reward which arouses individual covetousness for administrative and community leaders and for the various socio-cultural components (ethnic groups, religious denominations, trade groups, etc.). Since the appointment posts are quantitatively limited, the competition between individuals and communities through appointment exposes the country to more conflict than cohesion.

\section{References}

Cameroun - Gouvernement - Train de vie: Enquête sur les salaires et avantages des Ministres - Ce que nos ministres coûtent à l'Etat : Cameroon. Accessed on 20/3/2017

http://www.africapresse.com/comment-biya-nomme-ses-ministres. 7 Apr 2013. Accessed on 24/02/2017

Corcuff, P. (1995). les Nouvelles sociologies, Paris, Nathan.

Crozier, M., \& Erhard, F. (1992). L'acteur et le système : les contraintes de l'action collective Paris, Edition du Seuil.

De Visscher, Christian et Le Bussy, Gauthier, La politisation de la fonction publique : quelques réflexions d'ordre comparatif https://pyramides.revues.org/538. 3/2001 Accessed on 20/02/2017 
Essomba, Dieudonné is an economist and former official of the Ministry of the Economy of Planning and Regional Development (MINEPAT) (C) Integration.org: Interview by Thierry Ndong 12/12/2016 http://fr.allafrica.com/stories/201612121001.html

Geschiere, P. (1995). Sorcellerie et Politique en Afrique, Paris, Karthala https://www.237online.com http://www.lefigaro.fr/international/2011/10/27/01003-20111027ARTFIG00765-le-camerounnoyaute-par-les-socie tes-secretes.php Updated on 10/28/2011 at 12:58 am. Accessed on 03/01/2017

INS, Jeunes et marché du travail au Cameroun en 2010 http://www.statistics-cameroon.org. Accessed on 24/02/2017

Jean-François, B. (1979). l'Etat au Cameroun, Paris, Presses de la Fondation nationale des sciences politiques

KAKDEU, Louis-Marie (2014). Les cinq réformes nécessaires dans l'administration publique en Afrique, www.LibreAfrique.org Le 17 novembre 2014. Accessed on 11/02/2017

La Tribune de l'Est, a weekly published in Yaoundé, edition of Monday 27 January 2017

L'Epervier (2013). Cameroun - Remaniement ministériel: Et si Paul Biya prolongeait le suspens jusqu'en 2014 ? Wed, 25 Dec. 2013 https://www.237online.com Accessed on 25/02/2017

Mandjack, A. (2017). «L'hypothèse du pouvoir confisque au Cameroun ou «le triangle équilatéral » de Roger Gabriel Nlep », in Les Cahiers de Developpement du Droit, université de Douala www.peuplesawa.com. 2007 Accessed on 07/01/2017

Mulder, P. (2017). Bureaucratic Theory by Max Weber. from Tools Hero: https://www.toolshero.com/management/bureaucratic-theory-weber/ Accessed on 20/09/2017

Ndongo, C. (2016). «mon idée de la fonction de directeur général de la CRTV » in Cameroon Radio Television http://www.journalducameroun.com le 04.07.2016 Accessed on 24/02/2017

Nkom, Hervé in Jeune Afrique $\mathrm{N}^{\circ}$ 2674-2675 from 8 to 21 April 2012

Parfait, N. S. (2007). «RDPC: 21 membres pour auditionner M. Adama Modi», in Repères, 30-Sep-2007 http://www.cameroon-info.net. Accessed on 24/02/2017

Pigeaud, F. (2011). Au Cameroun de Paul Biya Paris Karthala, p. 71 This was lived by us during the 2011 presidential election campaign.

UNDP's 2016 Human Development Index

Zoé, J., \& L'actu, S. (2013). http://www.africapresse.com/fonction-publique-labsenteisme-est-roile 23 Février 2013

\section{Copyrights}

Copyright for this article is retained by the author(s), with first publication rights granted to the journal.

This is an open-access article distributed under the terms and conditions of the Creative Commons Attribution license which permits unrestricted use, distribution, and reproduction in any medium, provided the original work is properly cited. 